\title{
The Connection betweeen Unemployment and Migration at the Level of Hunedoara County and Town
}

\author{
Ph. D. Tiberiu Dîscă \\ University Lecturer, "Vasile Goldis" Western University of Arad
}

\begin{abstract}
The population of Hunedoara County has manifested after the Revolution of December 1989 a continuous downward trend. According to National Statistics Institute in Hunedoara County, in 2012, at the last population census there was only a number of 418,545 people representing the constant population and since 2016 it had decreased with almost $5 \%$ in 4 years but counting from 1992 the decrease is of almost $28 \%$. As far as concerns migration, the official figures of the number of the temporarily absent people left abroad for a shorter than a 12 months' period it was 5,510 and the number of those who were left for a period longer than a year it was 15,215. As follows, the total numbe'r of migrants was 20,725 which represents a percentage higher than $4 \%$ from the total number of the population. Comparing the data received from the AJOFM Hunedoara (the statistics is effectuated every year in August) with those obtained from the CJRAE Hunedoara (statistics reported every year in February), - excepting the year 2015- when the effect of the liberalisation of the labour market in Great Britain can be remarked, it can be noticed a descendent evolution of the number of unemployed which fact drags a decrease of the children with migrant parents. On the other hand, a very important decline of the unemployment in 2017 resulted into a diminution of the parents who would leave abroad in the following year.
\end{abstract}

Keywords: migration, Hunedoara, statistics, number of unemployed, children who have migrant parents, school

\section{Introduction}

The migration of Romanian people after 1990 has been considered a continuously dynamic and wide social phenomenon. It can be noticed that consulting the specialized literature that totally different figures are obtained from various sources, fact which can induce the idea of a lack of concensus and disparity between the existing data and the reality. Chipea and Bălțătescu ( 2010, p. 110) mention the fact that the Romanian authorities "underappreciate the number of children left behind", Sandu (2010, p. 11) stated that "the information is chronically deficient", he also offers as explanation of this situation three possible causes: the first which deals with the nature of the phenomenon, the second one is the low interest of the institutions and the third is presented as "the reduced capacity of a scientific answer from the specialized community".

The National Institute of Statistics ( an official institute with a high degree of credibility) offers the following information concerning migration

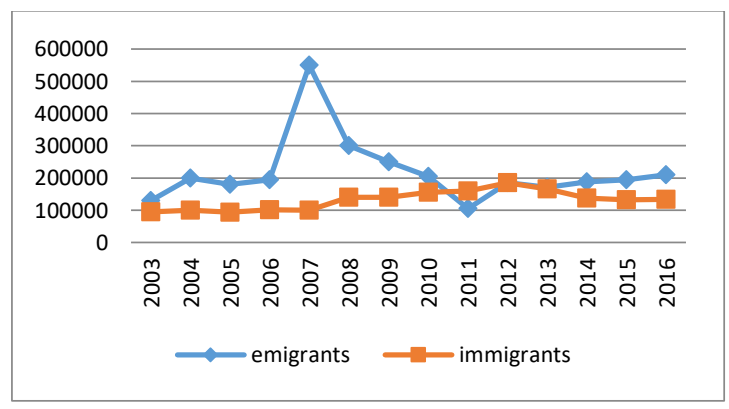

Figure 1. The evolution of the migration in Romania between 2003-2016 from the perspective of the flow of emigrants and migrants ( source NIS- Tempo Online Database) 
It can be distinguished a top of the emigration around the year 2007 ( in 2007 at 1st of January Romania joined the EU) and for the other years taken into consideration it is outlined an average of about 200,000 of emigrants.

Based on these figures, the total number of the Romanian emigrants is estimated by the UN at 3,4 million people, figure which places Romania on the second place in the world after Syria at the level of 2005. ( UN report about migration 2015)

The equivocal and uncertain situation concerning the Romanian migration after 1989 can be correlated by the European statistics as destination countries for the Romanian emigrants. According to the published data by the National Institute for Statistics from Italy, the number of the Romanian residents in Italy on the 1st of January 2011 was 969,000 (ISTAT, 2011). The Ministry of Labour and Immigration from Spain mentions the number of 842,000 resident Romanians in Spain in 2011 ( Ministerio de Trabajo e Inmigración, 2011,), a total of 1,811,000 Romanians inscribed in the administrative registers of the two countries. "At these figures it is added a number of Romanian people who live on the territory of these two countries without being registered and without being part of the official statistics, that gives a final number of about 2 million people. If we add the numbers concerning Romanian people in other countries representing important destinations of the Romanian migrants as - Germany, France, Greece, Austria, Ireland, Hungary- the total number exceeds 2,5 million." (Ghetau, 2012, p.10-11).

Comparing the censuses from 2002 and 2011 the result is a recession of 2,638,000 persons. Taking into consideration that the natural decrease was of 424,000 persons and the NIS offers the figure of 910,000 persons left abroad for a period of at least 12 months, which means that that 1,3 million from those left abroad were not registered in households within the 2011 census. For this reason Mr. Ghetau proposes the use of the "population estimating equation ", assuming all the risks what a this sort of approach can generate.

\section{Hunedoara County and the Migration}

In the absence of a clear statistics at national level, we try a statistics at the level of Hunedoara County.

The population of Hunedoara County has manifested after the 1989 December Revolution a continuous decreasing trend and we can say that in certain periods this trend was a massive one, as the following graph shows:

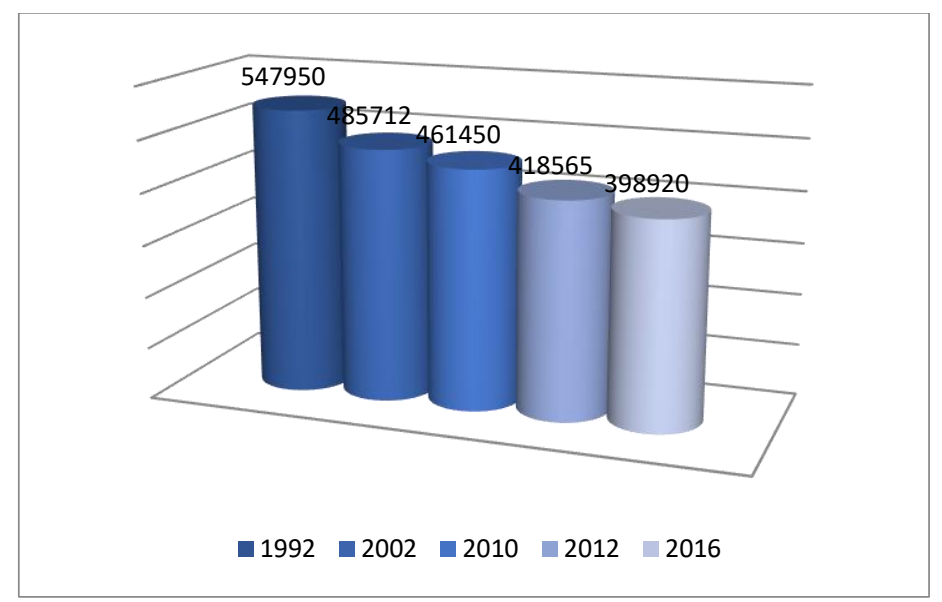

Figure 2. The downward evolution of Huneedoara County (source NIS -Tempo Online database)

According to National Institute of Statistics, in Hunedoara county in 2012 at the last census, there a was a number of 418,565 people as settled population and until 2016 this number decreased to 398,920- an almost 5\% diminution, counting from 1992 the decrease is almost of $28 \%$.

Concerning the migration, the number of persons who were temporarly absent- left abroad for a shorter period than 12 months, according to the official figures, was 5,510 and the number of those who were left for a longer period than a year was 15,215 . In conclusion, the total number of migrants is 20,725 , that represents $4,7 \%$ from the total population. 
A more accurate statistical situation is that representing the number of parents who have school and prescool ages and they are left abroad, because the teachers know the best the situations of these children.

According to the data provided by CJRAE ${ }^{1}$ Hunedoara, at the beginning of the 2015-2016 school year there was a number of 4,340 of children whose parents were abroad. This figure includes the children who were studying in the primary and secondary education system in Hunedoara County, namely from the kindergarten to the 12th grade. In April 2017, when the centralization of data for the 2016-2017 school year was realized there was a number of 4,387 students. We mention that these data were obtained from the internal reports of the CJRAE, this institute usually does not make public this sort of figures. These statistics are realized as a result of centralization of the reports sent by school counsellors from each educational institute.

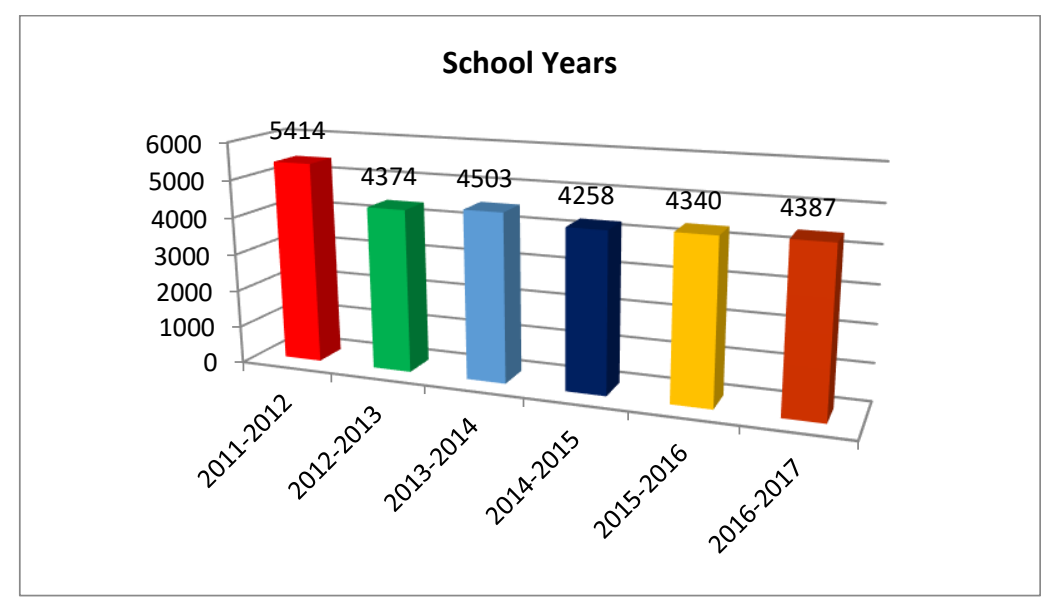

Figure 3. The evolution of the number of children whose parents are left abroad at Hunedoara County level ( source CJRAE Hunedoara).

Regardless of the period under review, the most alarming problem by far remains the educational environment in which the children remain, the persons to whom these children would be entrusted after the biological parents left abroad, supposing that they had been taken care of the children's education.

For April 2017 the situation is represented in the following graph:

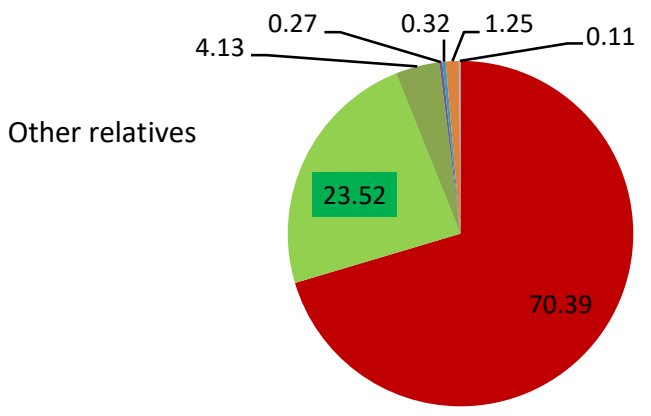

To one parent

Figure 4. The persons who are taking care of the children whose parents are left abroad (source CJRAE Hunedoara)

${ }^{1}$ CJRAE- Hunedoara Country Centre for Resources and Educational Assistance 
From the 4,387 students whose parents were left abroad in the 2016-2017 school year, 547 ( $12,47 \%$ ) had both parents working in foreign countries; $1,538(35,06 \%)$ had their mother left; 2,282 had their father left and $20(0,46 \%)$ had one parent left abroad without being specified by the educational institutes which one.

A special case is that one where the child comes from a single parent family and this parent is the sole support of the family: in 454 of the cases $(76,05 \%)$ as sole support - the mother was left left, in 134 cases $(22,45$ the father was left as sole support and in 9 cases $(1,51 \%)$ is not specified the sole support parent who was left.

Generally the single parent families are those which confront more difficult problems connected to the support of the child, the single mother sole support families usually confront financial difficulties. ( Voinea, 2010, p.16).

Consulting the reports of the AJOFM ${ }^{1}$ Hunedoara we can make an analysis the Hunedoara town area and so we can make a connection between the evolution of the number of unemployed and the evolution of the number of children with migrant parents:

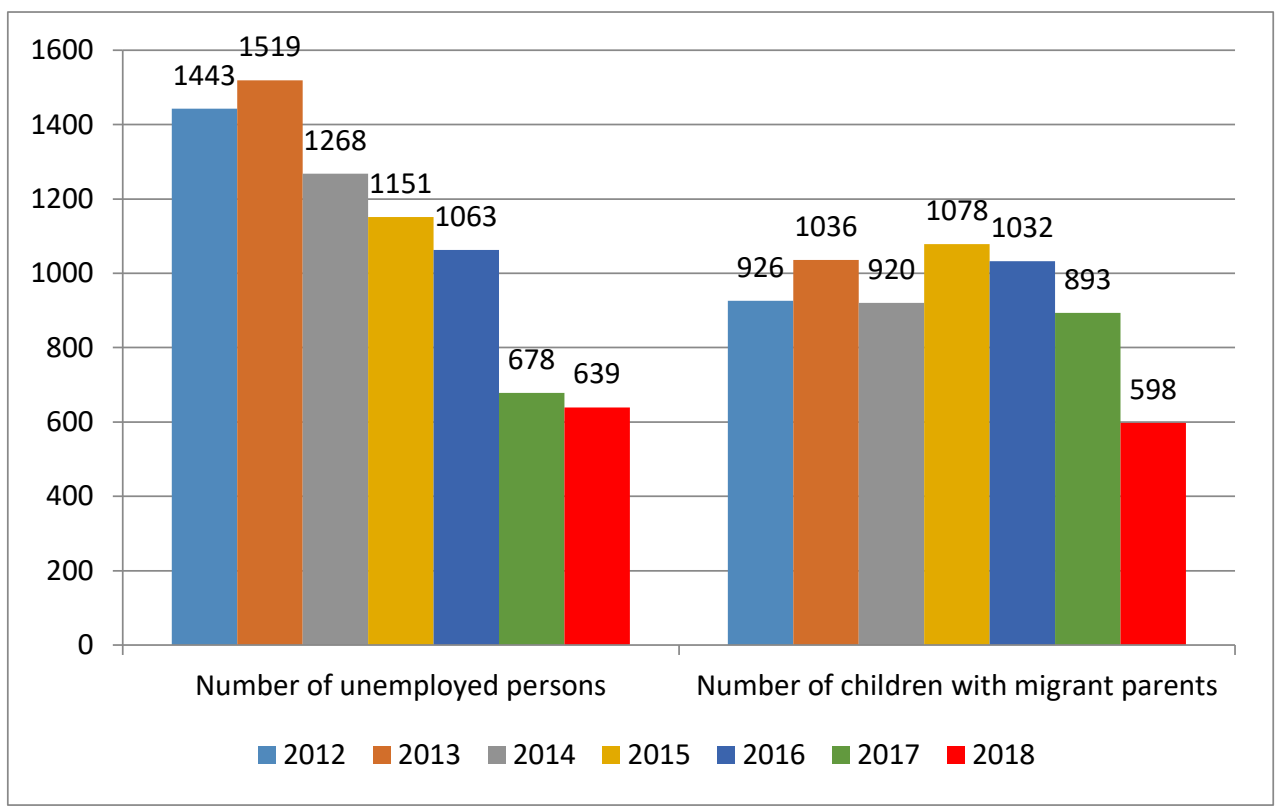

Figure 5. The evolution of the number of the unemployed and the number of the children whose parents are migrants in Hunedoara town (2012-2018)- source AJOFM an CJRAE Hunedoara)

Comparing the data obtained from the AJOFM Hunedoara ( the statistics is made each year in August) with the data from the CJRAE Hunedoara ( the statistics are made each year in February) we can notice the way how- excepting the year 2015- the downward evolution of the number of unemployed drags a diminution of the number of children who have migrant parents.

The cause of the mismatch for 2015 is the result of the elimination of the restrictions on the British labour market for Romanian citizens beginning with the 1 st of January.

\section{Conclusions}

In conclusion, it can be stated that:

\footnotetext{
${ }^{1}$ AJOFM- National Emplyoment Agency
} 
The evolution of the unemployment in Hunedoara county is in a tight connection with the evolution of the students whose parents are migrants. With the exception of the 2015 ( the year when the effects of the liberalization of the British labour market became obvious), the number of the unemployed and the number of the children with migrant parents has permanently decreased since 2012- this the year when educational institutes started to establish reports regarding the children with migrant parents.

In the most of the cases, the children are left in the care of one of the parents $(72 \%)$, although there is a large number of children who are entrusted to the grandparents, to relatives or to some close people, the number of these cases has been increasing with year by year.

The year 2013 is marked by an important increase of the number of unemployed, reaching a maximum of 1,519 persons and this is the reason for the maximum level of the number of migrant parents ( 1,036 cases).

The year 2017 brought an important decrease of almost 33\% of the number of unemeployed persons by creating opportunities for new jobs. This important diminution is the reason of an obvious decrease in 2018 of the migrant parents with the same percentage $(33 \%)$.

The reported downward trend of the unemployment at the level of Hunedoara town in August 2018 makes possible to predict a decreasing number of the migrant parents.

\section{Bibliography}

[1] Chipea, F., Bălţătescu S., (2010), Copiii lăsaţi acasă de emigranţi. Studiu în judeţul Bihor, Sociologie Românească, vol. VIII nr. 4

[2] Ghețău V., (2012), Drama noastră demografică, Editura Compania, București;

[3] Institutul Național de Statistică, http://colectaredate.insse.ro/phc/public.do?siteLang=ro

[4] ISTAT, 2011, https://www.istat.it/it/files/2013/12/Notadiffusione_stranieri 20122013.pdf

[5] Ministerio de Trabajo e Inmigración, (2011), http://www.mitramiss.gob.es/estadisticas/ANUARIO2011/EXR/index.htm

[6] Sandu D., (2010), Lumile sociale ale migraţiei româneşti în străinătate, Editura Polirom, Iaşi;

[7] United Nations, Department of Economic and Social Affairs, Population Division (2016). International Migration Report 2015: Highlights (ST/ESA/SER.A/375) 